\title{
Care for the critical patient undergoing point-of-care testing: integrative review
}

\author{
Cuidados ao paciente crítico na realização do exame de imagem no leito: revisão integrativa \\ Cuidado del paciente crítico en la realización del examen de imagen en la cama: revisión integrativa
}

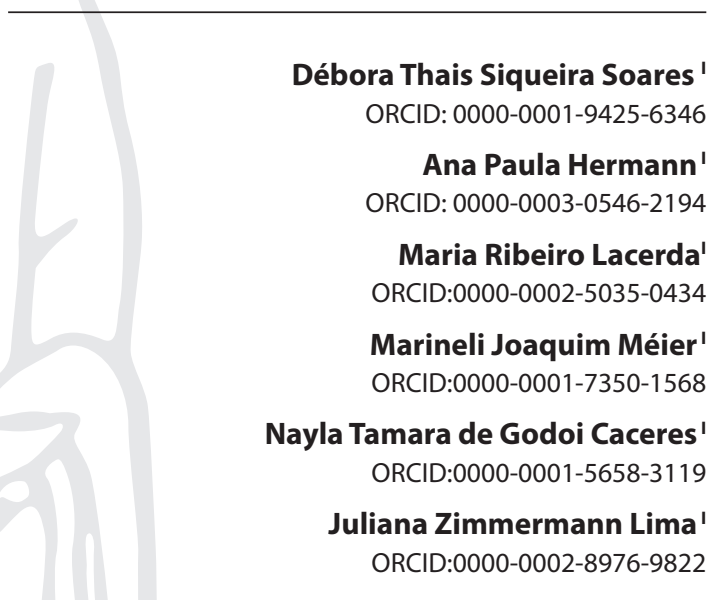

'Universidade Federal do Paraná. Curitiba, Paraná, Brazil.

How to cite this article:

Soares DTS, Hermann AP, Lacerda MR, Méier MJ, Caceres NTG, Lima JZ. Care for the critical patient undergoing point-of-care testing: integrative review. RevBrasEnferm. 2020;73(6):e20180948. doi: http://dx.doi.org/10.1590/0034-7167-2018-0948

Corresponding author: Débora Thais Siqueira Soares E-mail:dtssiqueira@gmail.com

EDITOR IN CHIEF: Dulce Barbosa ASSOCIATE EDITOR: Antonio José de Almeida Filho

Submission: 04-14-2019

Approval: $02-12-2020$

\begin{abstract}
Objective: to identify, based on the evidence, point-of-care testing in bedbound in critically ill patients. Method: integrative review, carried out through search in Pubmed, Virtual Health Library, Joanna Briggs Institute, The British Institute of Radiology, Brazilian Radiology, and Google Scholar databases. We used the PICO research strategy and selected articles published from 2013 onwards, which presented information about point-of-care testing. Results: the different interventions found in the analysis of the 23 selected articles allowed the thematic grouping of care related to safety in communication, patient identification, care with devices, and the prevention and control of infection, which can be used in point-of-care testing. Final considerations: The care described in the evidence provided support for validating a safe care protocol for critically ill patients undergoing imaging studies in bed.

Descriptors: Critical Care; Nursing Care; Patient Care Team; Point-of-Care Testing; Patient Safety.
\end{abstract}

\section{RESUMO}

Objetivo: identificar nas evidências os cuidados a serem aplicados na realização de exames de imagem no leito em pacientes críticos. Método: revisão integrativa. Realizada consulta às bases de dados: Pubmed, Biblioteca Virtual em Saúde, Joanna Briggs Institute, The British Institute of Radiology, Radiologia Brasileira e Google acadêmico. Utilizada a estratégia PICO de pesquisa, selecionados artigos publicados a partir de 2013, que apresentaram informações sobre cuidados na realização de exames de imagem no leito. Resultados: as diferentes intervenções resultantes da análise dos 23 artigos selecionados permitiram o agrupamento temático dos cuidados relacionados à segurança na comunicação, identificação do paciente, cuidados com dispositivos e prevenção e controle de infecção, os quais podem ser utilizados na realização de exames de imagem no leito. Considerações finais: os cuidados descritos nas evidências forneceram subsídios para a validação de um protocolo de cuidado seguro ao paciente crítico submetido a exames de imagem no leito.

Descritores: Cuidados Críticos; Cuidados de Enfermagem; Equipe de Assistência ao Paciente; Diagnóstico à Beira do Leito; Segurança do Paciente.

\section{RESUMEN}

Objetivo: identificar em la evidencia la atención que se debe aplicar al realizar pruebas de imágen esen cama en pacientes críticos. Método: revisión integradora. Se consultaron las bases de datos: Pubmed, Biblioteca Virtual em Salud, Joanna Briggs Institute, The British Institute of Radiology, Radiología Brasileña y académico de Google. Utilizando la estrategia de investigación PICO, se seleccionaron artículos publicados a partir de 2013, que presentaban información sobre laatención al realizar pruebas de imagenen cama. Resultados: las diferentes intervenciones resultantes del análisis de los 23 artículos seleccionados permitieron la agrupación temática de la atención relacionada com la seguridade en la comunicación, la identificación del paciente, la atención con dispositivos y la prevención y el control de infecciones, que pueden utilizarse para realizar pruebas de imagen em la cama. Consideraciones finales: la atención descrita em la evidencia proporciono apoyo para lavalidación de un protocolo de atención segura para pacientes críticos sometidos a imágenes de cama.

Descriptores: Cuidados Críticos; Atención de Enfermería; Grupo de Atención al Paciente; Pruebas em el Punto de Atención; Seguridad del Paciente. 


\section{INTRODUCTION}

The World Health Organization (WHO) defines patient safety as reducing the risk of unnecessary harm associated with health care to an acceptable minimum. Risk is the possibility of an incident, which is an event or circumstance that can result in unnecessary damage. Damage is the impairment of the body's structure or function that causes physical, social, or psychological disability or dysfunction ${ }^{(1)}$.

Patient safety in health services must be guided by safety evidence ${ }^{(2)}$. The main challenge for professionals working in critical care units is to ensure patient safety, given their exposure to risks with possible damage resulting from the various procedures of point-of-care testing. A critical patient is one who requires intensive care from a multidisciplinary team in specialized units ${ }^{(3)}$.

To minimize these risks and promote safe care, WHO encourages the adoption of various guidelines related to proper care practices, among them the six International Goals for Patient Safety (IPSG). These goals aim to reduce risks and incidents regarding patient safety in health services, to correctly identify the patient, to improve effective communication, to improve the safety of high-alert medications, to ensure safe surgery, site procedure, and correct patient, to reduce the risk of health care-associated infections through frequent hand hygiene, to reduce the risk of patient harm resulting from falls and pressure injuries in hospital environments, to ensure quality in care environments ${ }^{(4-5)}$.

The specialized units have different equipment for carrying out diagnoses and treatments, including hemodynamic monitoring, which is one of the most critical procedures for patient care in a critical unit, as it allows for accurate data that assist in rapid intervention, avoiding complications to the patient and failures in assistance ${ }^{(6)}$.

Although monitoring is a non-invasive procedure, most procedures performed on critically ill inpatients are invasive, such as orotracheal intubation, tracheostomy, nasogastric or orogastric catheter, bladder, central or peripheral access. Hospitalization abruptly interferes with the subject's way of life, who is unable to exercise their autonomy, nor their attitudes, such as personal hygiene, food, eliminations, and others ${ }^{(7)}$.

In this sense, it is possible that, in addition to invasive procedures, patients are subjected to point-of-care testing. The number of diagnostic tests has increased significantly in recent years, including computed tomography, magnetic resonance, hemodynamics, interventional procedures, and X-rays ${ }^{(2)}$, being the X-rays and ultrasonography (US) frequently used at point-ofcare testing for their portability and accessibility ${ }^{(8)}$.

Critical patients are subjected daily to various point-of-care testing, which has an inherent risk to the procedure. These risks, as well as the complexity of the patients, demand specific attention and care from the professionals.

Given the technology used in critically ill patients, a trained, agile team capable of predicting risk situations is necessary, avoiding injuries to the patient $t^{(9)}$. The nurse who works in critical units must ensure safe and humanized care with the team, being in charge of evaluating the patient and the situations to which he/she is exposed and systematizing the assistance, choosing the most appropriate resource or care ${ }^{(6)}$. A prepared professional is required, able to attend to physiological changes, complications, and the patient's needs during treatment ${ }^{(10)}$.
The investigation of the theme emerged from the identification of the knowledge gap regarding the necessary care for point-of-care testing in critically ill patients.

\section{OBJECTIVE}

To Identify the scientific evidence on safety care for critically ill patients undergoing point-of-care testing.

\section{METHODS}

\section{Study design}

We opted for an integrative literature review, which is a method that groups and synthesizes results, as it elaborates a comprehensive explanation of a specific phenomenon. Consequently, the conclusions are established through a critical evaluation of different methodological approaches ${ }^{(11)}$.

\section{Methodological procedure}

The stages were: identification of the theme and selection of the research question; establishment of inclusion and exclusion criteria; identification of pre-selected and selected studies; categorization of studies; analysis and interpretation of results; and, finally, the presentation of the knowledge review/synthesis ${ }^{(12)}$. The guiding question is: What are the necessary precautions forsafety point-of-care testingin a critical patient?

\section{Data collection and organization}

From October 2017 to January 2018, we checked the following databases:Virtual Health Library (BVS), Joanna Briggs Institute (JBI); The British InstituteofRadiology (BRI); Brazilian Radiology(CRB) and Google Scholar. Articles in English, Spanish, and Portuguese, available in full, published from 2013 onwards, withabstracts and information on safety point-of-care testing for critical patients, were included. Duplicate studies in different databases, and that did not meet the inclusion criteria were excluded.

PICO strategy was adopted. In its acronym, the letter P stands for patients or population, in this case, are the patients (adult, pediatric and neonatal), submitted to point-of-care testing for diagnosis, which include Radiology exams (X-ray), Ultrasound, Echocardiography, Endoscopy, Fibrobronchoscopy, Electroencephalogram and Colonoscopy; I stands for intervention or indicator, defined by the safe care for the patient submitted to imaging exams/diagnoses (safe care is to perform the imaging diagnosis without incidents with or without damage); $C$ stands for comparison or control, which does not apply to this research; and $\mathrm{O}$ stands for outcome, which means clinical outcome, result, safe care in making the image diagnosis without exposing the patient to falls, loss of devices (monitoring electrodes, catheters, probes, drains and/or dressings), extubation, bronchoaspiration, bleeding, cross-infection and pain during the imaging exam ${ }^{(13)}$.

Medical Subject Headings (MeSH) descriptors and Health Sciences descriptors (DECS) were defined and then articulated with Boolean operators: OR and AND (Diagnostic imaging OR 
Patient Safety OR Critical Care OR Nursing Care OR Point-of-Care Testing OR Diagnostic Techniques and Procedures OR Neurologic Examination OR Diagnostic Techniques; Neurological OR Diagnostic Techniques, Cardiovascular OR Diagnostic Techniques digestive System OR Endoscopy OR Digestive System OR Radiology OR Radiology Interventional OR Diagnostic Techniques); (Care protocol AND Diagnostic imaging OR Cross Infection OR Airway Extubation OR Pneumonia OR Aspiration OR Respiratory Aspiration of Gastric Contents OR Accidental Falls OR Monitoring OR Device Removal OR Pain).

\section{Work stages}

The initial search found 5,175 articles. After reading all titles, abstracts, 101 articles were selected for full reading, resulting in 23 articles suitable for analysis.

Two researchers stated the relevance of the selected evidence concerning the research objective. For data extraction, an instrument containing: article title, authors, periodical (volume, number, page and year), objective, method, main results and conclusion, showing the care to be applied to critical patients submitted to bed image was created, and these were recorded in a Microsoft Office Excel ${ }^{\circledR}$ spreadsheet.

Figure 1 illustrates the selection process for the articles in this integrative review.

\section{RESULTS}

The 23 selected articles were published in the following years: nine, in 2018; five, in 2017; four, in 2016; four, in 2015; and one publication in 2013.

Chart 1 show the main results of the 23 selected publications, highlight the characterization of the evidence, the methodological aspects, and the results.

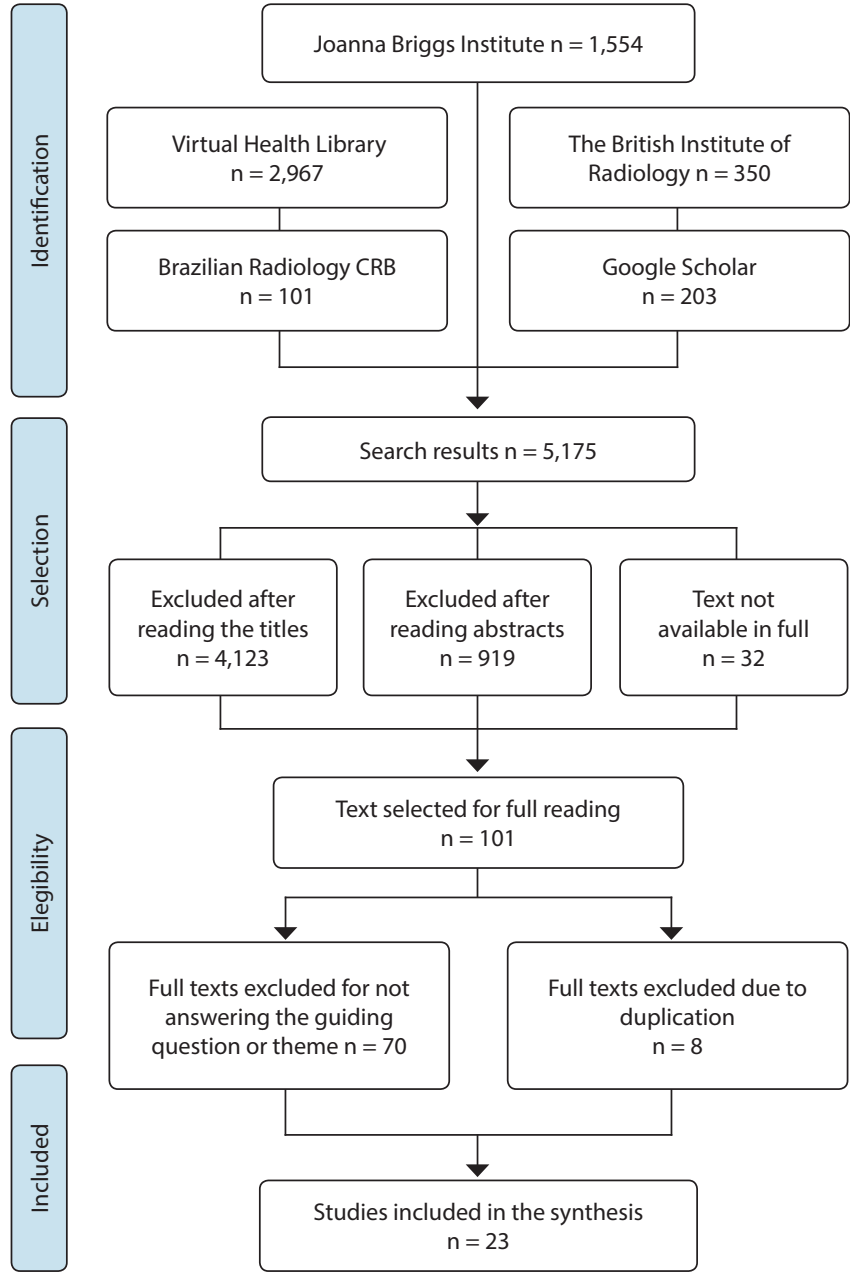

Figure 1 -Diagram of identification, selection and inclusion of integrative review studies

Chart 1 - Characterization and main results of publications included in the integrative review in selection order

\begin{tabular}{|c|c|c|c|}
\hline Article / journal/year & Tipyofstudy / sample & Objective & Mainresults \\
\hline $\begin{array}{l}\text { A } 1^{(14)} \\
\text { Arq Bras Cardiol: } \\
\text { Imagem Cardiovasc. } \\
2016 .\end{array}$ & $\begin{array}{l}\text { Observation and } \\
\text { evaluation of image } \\
\text { quality in regarding to } \\
\text { the decubitus position. } \\
\text { Total of } 67 \text { patients. }\end{array}$ & $\begin{array}{l}\text { To assess whether changing the patient's } \\
\text { position during the exam could have an } \\
\text { influence on the technical quality of the } \\
\text { images and whether additional factors could } \\
\text { limit collecting adequate images in the bed. }\end{array}$ & $\begin{array}{l}\text { Patient's positioning on the bed is extremely } \\
\text { important for obtaining good quality images. } \\
\text { About } 90 \% \text { of the images were considered } \\
\text { good/excellent when the patients were placed } \\
\text { in the Left Lateral Decubitus. }\end{array}$ \\
\hline $\begin{array}{l}\mathrm{A} 2^{(15)} \\
\text { Revista Brasileira de } \\
\text { Enfermagem. } 2017\end{array}$ & $\begin{array}{l}\text { Descriptive study, with a } \\
\text { quantitative approach of } \\
\text { methodological validation } \\
\text { of an instrument. }\end{array}$ & $\begin{array}{l}\text { To develop and validate a nursing care } \\
\text { protocol for patients with Ventricular Assist } \\
\text { Device (VAD). }\end{array}$ & $\begin{array}{l}\text { Protocol composed of } 10 \text { actions: the } \\
\text { appropriate nutritional support, the } \\
\text { assessment of the patient's pain, the correct } \\
\text { analgesia and the prevention of infectious } \\
\text { processes are highlighted. }\end{array}$ \\
\hline $\begin{array}{l}\mathrm{A} 3^{(16)} \\
\text { Acta Scientiarum. } \\
\text { Health Sciences. } \\
2016 .\end{array}$ & $\begin{array}{l}\text { Prospective observational } \\
\text { study. Adult patients } \\
\text { undergoing thoracic } \\
\text { drainage with a water seal. }\end{array}$ & $\begin{array}{l}\text { To evaluate the management of closed chest } \\
\text { drainage systems through the analysis of } \\
\text { adult patients, as well as standardize the care } \\
\text { protocol for chest drainage and minimize its } \\
\text { complications. }\end{array}$ & $\begin{array}{l}\text { Protocol composed of } 12 \text { actions. Therapeutic } \\
\text { success is evidenced and it is directly related to } \\
\text { the qualification and continuous training of the } \\
\text { patient's caregivers undergoing chest drainage. }\end{array}$ \\
\hline $\begin{array}{l}\text { A4 }{ }^{(17)} \\
\text { Essentia. } 2017\end{array}$ & $\begin{array}{l}\text { Integrative Review. A } \\
\text { total of } 12 \text { articles were } \\
\text { selected. }\end{array}$ & $\begin{array}{l}\text { To identify the scientific evidence about the } \\
\text { nursing care provided to patients undergoing } \\
\text { mechanical ventilation in the ICU. }\end{array}$ & $\begin{array}{l}\text { Nursing care for artificially ventilated patients } \\
\text { requires nurses to have prior knowledge and } \\
\text { skills so that patients' care needs are met. }\end{array}$ \\
\hline $\begin{array}{l}\mathrm{A} 5^{(18)} \\
\text { Revista Gaúcha de } \\
\text { Enfermagem. } 2015\end{array}$ & $\begin{array}{l}\text { Cross-sectional, analytical } \\
\text { study with a quantitative } \\
\text { approach. A total of } 793 \\
\text { observations were made. }\end{array}$ & $\begin{array}{l}\text { To identify the adherence of health } \\
\text { professionals in an Intensive Care Unit } \\
\text { regarding the five moments of hand-washing } \\
(\mathrm{HW}) \text { recommended by WHO. }\end{array}$ & $\begin{array}{l}\text { In } 446(56.2 \%) \text { observations, there was no HW. } \\
\text { HW with soap and water was more frequent } \\
(32 \%) \text { compared to rubbing with alcohol } \\
(11.8 \%) \text {. The HW adherence rate was } 43.7 \% \text {. }\end{array}$ \\
\hline
\end{tabular}




\begin{tabular}{|c|c|c|c|}
\hline Article / journal/year & Tipyofstudy / sample & Objective & Mainresults \\
\hline $\begin{array}{l}\text { A6 } 6^{(19)} \\
\text { Revista Brasileira de } \\
\text { Enfermagem. } 2015 .\end{array}$ & $\begin{array}{l}\text { Methodological study. } \\
\text { Participation of five } \\
\text { specialists. }\end{array}$ & $\begin{array}{l}\text { Check the positioning recommendations } \\
\text { of newborns (NB) and build a standard } \\
\text { operating procedure protocol (SOP) for } \\
\text { positioning NBs in the Neonatal Intensive } \\
\text { Care Unit (NICU). }\end{array}$ & $\begin{array}{l}\text { Correct positioning of the premature baby: } \\
\text { head of the bed raised to } 30^{\circ} \text {. Positions: a) flat or } \\
\text { supine position: maximum flexion and support } \\
\text { of the scapular zone; b) Lateral decubitus: Slight } \\
\text { flexion of the trunk and head in the midline } \\
\text { and flexion of the arms; c) prone position or } \\
\text { pronation: flexion of the spine, slight pelvic } \\
\text { elevation, correct feet angle and nesting. }\end{array}$ \\
\hline $\begin{array}{l}\mathrm{A} 7^{(20)} \\
\text { International Journal } \\
\text { of Evidence-Based } \\
\text { Healthcare. } 2015\end{array}$ & $\begin{array}{l}\text { A convenience sample, } \\
\text { selected } 33 \text { nurses. }\end{array}$ & $\begin{array}{l}\text { To identify the best available evidence and } \\
\text { develop an evidence-based clinical audit project } \\
\text { to use as a guide to assess current nursing, } \\
\text { practice and implement a change strategy to } \\
\text { increase compliance with best practice standards } \\
\text { for nursing in patients with chest tubes. }\end{array}$ & $\begin{array}{l}\text { A total of } 94 \% \text { of participants agreed that the } \\
\text { use of the checklist improved patient care and } \\
90 \% \text { agreed that it was useful for performing } \\
\text { physical examinations on patients. Regarding } \\
\text { workload: } 35 \% \text { of nurses did not notice an } \\
\text { increase in workload. }\end{array}$ \\
\hline $\begin{array}{l}\text { A } 8^{(21)} \\
\text { Radiologia Brasileira. } \\
2015 .\end{array}$ & $\begin{array}{l}\text { Literature review, without } \\
\text { description of the } \\
\text { method used. }\end{array}$ & $\begin{array}{l}\text { To review the main concepts related to } \\
\text { the topic addressed in order to better } \\
\text { understand them, thus making it possible to } \\
\text { establish strategies for safe practice without } \\
\text { compromising the quality of the exam and } \\
\text { the operator's productivity. }\end{array}$ & $\begin{array}{l}\text { The use of gloves is recommended during all } \\
\text { tests and should be used to remove the used } \\
\text { preservative and to wash the transducer. Hand } \\
\text { asepsis is essential for starting a new exam. } \\
\text { Cleaning/ disinfecting the probes should be } \\
\text { systematic and routinely. }\end{array}$ \\
\hline $\begin{array}{l}\mathrm{A} 9^{(3)} \\
\text { Revista Online de } \\
\text { Pesquisa: Cuidado é } \\
\text { Fundamental. } 2018 .\end{array}$ & $\begin{array}{l}\text { Descriptive, retrospective, } \\
\text { documentary research } \\
\text { with a quantitative } \\
\text { approach. A total of } 360 \\
\text { printouts were analyzed. }\end{array}$ & $\begin{array}{l}\text { To analyze the unplanned removal of invasive } \\
\text { devices in an intensive care unit. }\end{array}$ & $\begin{array}{l}\text { The enteric catheter for food stood out among } \\
\text { those devices removed in an unplanned manner } \\
(42 \%) \text {. The reasons for which the removal was } \\
\text { done were: removed by the patient (33\%), } \\
\text { obstruction (30\%) and accidental loss (21\%). }\end{array}$ \\
\hline $\begin{array}{l}\text { A10 (22) } \\
\text { JBI Database of } \\
\text { Systematic Reviews } \\
\text { and Implementation } \\
\text { Reports. } 2018\end{array}$ & $\begin{array}{l}\text { Systematic review. It } \\
\text { included patients who } \\
\text { underwent a CT scan } \\
\text { with contrast. }\end{array}$ & $\begin{array}{l}\text { To identify risk factors and interventions that } \\
\text { prevent or reduce the extravasation of the } \\
\text { contrast medium in patients undergoing } \\
\text { computerized tomography examination. }\end{array}$ & $\begin{array}{l}\text { The amount of extravasated fluid, the venous } \\
\text { access and the catheter's permanence time and } \\
\text { the patient's characteristics can be a risk factor } \\
\text { for extravasation, recent hospitalization. }\end{array}$ \\
\hline $\begin{array}{l}\text { A11 } 1^{(23)} \\
\text { Journal of Specialized } \\
\text { Nursing Care. } 2018\end{array}$ & $\begin{array}{l}\text { Descriptive research } \\
\text { carried out through } \\
\text { systematic bibliographic } \\
\text { review. A total of } 10 \\
\text { articles were selected. }\end{array}$ & $\begin{array}{l}\text { To review the evidence-based guidelines } \\
\text { that will assist the intensive care nurse in the } \\
\text { identification and prevention of Surgical Site } \\
\text { Infections (SSI) in the postoperative period of } \\
\text { cardiac surgery, in the Intensive Care Unit. }\end{array}$ & $\begin{array}{l}\text { Proper assessment of the surgical site is } \\
\text { important. The nurse has a central role in the } \\
\text { maintenance of the surgical dressing and in the } \\
\text { evaluation of the surgical wound, in order to } \\
\text { detect early complications of infection. }\end{array}$ \\
\hline $\begin{array}{l}\mathrm{A} 12^{(24)} \\
\text { Journal of Specialized } \\
\text { Nursing Care. } 2018\end{array}$ & $\begin{array}{l}\text { Integrative bibliographic } \\
\text { research. A total of } 12 \\
\text { articles were selected. }\end{array}$ & $\begin{array}{l}\text { To analyze the scientific evidence available } \\
\text { for the prevention of infection associated } \\
\text { with bladder catheterization, with emphasis } \\
\text { on the Intensive Care Unit, through nursing } \\
\text { interventions. }\end{array}$ & $\begin{array}{l}\text { Nurse qualification guarantees the quality of } \\
\text { the care provided to the patient, and it must } \\
\text { follow protocols and guidelines as a way to } \\
\text { avoid damage to the health of the patient who } \\
\text { is already hospitalized in ICUs. }\end{array}$ \\
\hline $\begin{array}{l}\text { A13(25) } \\
\text { Journal of Specialized } \\
\text { Nursing Care. } 2018\end{array}$ & $\begin{array}{l}\text { Integrative literature } \\
\text { review. A total of } 10 \\
\text { articles were selected. }\end{array}$ & $\begin{array}{l}\text { To review evidence-based guidelines that will } \\
\text { assist the intensive care nurse in identifying } \\
\text { and treating nursing care conduct related to } \\
\text { infection control related to the Central Venous } \\
\text { Access device. }\end{array}$ & $\begin{array}{l}\text { Through good practices in the insertion, } \\
\text { handling and removal of the central venous } \\
\text { catheter, nurses can develop mechanisms to } \\
\text { prevent infections related to the use ofCVC. }\end{array}$ \\
\hline $\begin{array}{l}\text { A14(26) } \\
\text { Revista de } \\
\text { Administração em } \\
\text { Saúde. } 2018\end{array}$ & $\begin{array}{l}\text { Clinical audit study, } \\
\text { control and system } \\
\text { review. With a total of } 15 \\
\text { participants. }\end{array}$ & $\begin{array}{l}\text { To evaluate CVC-related nursing care in adult } \\
\text { and pediatric Intensive Care Units to compare } \\
\text { the conduct to the standardized protocol in } \\
\text { the institution and analyze the results, based } \\
\text { on the ANVISA guide entitled "Health Care- } \\
\text { Related Infection Prevention Measures" 2017. }\end{array}$ & $\begin{array}{l}\text { Regarding the use of PPE (gloves, mask, glasses } \\
\text { and cap) while performing CVC dressings, it } \\
\text { was noticed that } 1(6.7 \%) \text { nurse did not use } \\
\text { sterile gloves during the procedure, } 4 \text { ( } 26.7 \%) \\
\text { did not wear a mask, } 14 \text { ( } 93.4 \%) \text { did not wear } \\
\text { glasses, } 3 \text { did not wear a cap (20.0\%). }\end{array}$ \\
\hline $\begin{array}{l}\text { A15 } 5^{(27)} \\
\text { Revista Brasileira de } \\
\text { Enfermagem. } 2018\end{array}$ & $\begin{array}{l}\text { Descriptive and cross- } \\
\text { sectional study, with } 50 \\
\text { nurses. }\end{array}$ & $\begin{array}{l}\text { To describe determining factors in the } \\
\text { management of the hand hygiene procedure } \\
\text { performed by a group of nurses in Internal } \\
\text { Medicine services and to identify possible } \\
\text { challenges for public health. }\end{array}$ & $\begin{array}{l}\text { A total of } 90 \% \text { consider respecting the } \\
\text { existing hand hygiene recommendations at } \\
\text { the stipulated times. However, none of the } \\
\text { moments of hand hygiene with water and soap } \\
\text { were identified by all respondents. }\end{array}$ \\
\hline $\begin{array}{l}\text { A16 } \\
\text { Revista Uningá. } 2016\end{array}$ & $\begin{array}{l}\text { Integrative literature } \\
\text { review, with a qualitative } \\
\text { approach, totaling } 22 \\
\text { selected articles. }\end{array}$ & $\begin{array}{l}\text { To characterize the scientific production on } \\
\text { biosafety and precaution in the ICU and to } \\
\text { describe the factors that contribute to the } \\
\text { healthy environment in the ICU and the } \\
\text { habits of professionals, from } 2003 \text { to } 2012 \text {. }\end{array}$ & $\begin{array}{l}\text { Professionals neglect biosafety in their } \\
\text { daily work routine, exposing themselves to } \\
\text { occupational risks, a result strongly influenced } \\
\text { by organizational issues of the health } \\
\text { institution itself. }\end{array}$ \\
\hline $\begin{array}{l}\text { A17 (29) } \\
\text { DisciplinarumScientia. } \\
\text { Ciências da Saúde. } \\
2017\end{array}$ & $\begin{array}{l}\text { Integrative literature } \\
\text { review. A total of } 8 \\
\text { publications were } \\
\text { selected. }\end{array}$ & $\begin{array}{l}\text { To identify scientific productions at } \\
\text { national and international level on patient } \\
\text { identification through the use of wristbands } \\
\text { and their implications for safe care in the } \\
\text { hospital context. }\end{array}$ & $\begin{array}{l}\text { It was evident, the multiplicity of factors } \\
\text { involved in such a process and the great } \\
\text { challenge of health institutions in reaching } \\
\text { acceptable levels of conformities regarding the } \\
\text { identification process. }\end{array}$ \\
\hline
\end{tabular}




\begin{tabular}{|c|c|c|c|}
\hline Article / journal/year & Tipyofstudy / sample & Objective & Mainresults \\
\hline $\begin{array}{l}\text { A } 18^{(30)} \\
\text { Escola Anna Nery. } \\
2018\end{array}$ & $\begin{array}{l}\text { Integrative, exploratory } \\
\text { review study, which } \\
\text { resulted in } 15 \text { articles. }\end{array}$ & $\begin{array}{l}\text { To look for scientific evidence on the practice } \\
\text { of handoff in the ICU regarding the safety of } \\
\text { team members' communication about the } \\
\text { hospitalized patient. }\end{array}$ & $\begin{array}{l}\text { Missing, incomplete, or wrong information in } \\
\text { the handoff is highlighted, due to the lack of } \\
\text { standardization and preparation of this activity, } \\
\text { causing a delay in procedures or that are wrong } \\
\text { or not performed. The use of instruments } \\
\text { reduces the amount of information neglected, } \\
\text { casual conversations, and errors, improving } \\
\text { team satisfaction. }\end{array}$ \\
\hline $\begin{array}{l}\text { A19 } \\
\text { Revista Eletrônica } \\
\text { Acervo Saúde. } 2018\end{array}$ & $\begin{array}{l}\text { Integrative literature } \\
\text { review. A total of } 6 \\
\text { articles were selected. }\end{array}$ & $\begin{array}{l}\text { To analyze nursing care for bedridden } \\
\text { patients in the ICU through a literature review. }\end{array}$ & $\begin{array}{l}\text { Most studies evaluated the nurses' actions } \\
\text { and the need for a trained and experienced } \\
\text { intensivist to guarantee the quality of life of } \\
\text { patients who need their care. }\end{array}$ \\
\hline $\begin{array}{l}\text { A20 } \\
\text { Revista de Saúde } \\
\text { Pública do Paraná. } \\
2017\end{array}$ & $\begin{array}{l}\text { Exploratory-descriptive } \\
\text { study, based on } \\
\text { documents and } \\
\text { quantitative approach. } \\
\text { Direct observation of } 61 \\
\text { beds. }\end{array}$ & $\begin{array}{l}\text { To assess the adherence of health } \\
\text { professionals in the five moments of hand } \\
\text { hygiene in the ICUs of a pediatric hospital. }\end{array}$ & $\begin{array}{l}\text { It is observed that, just before contact with } \\
\text { the patient, there is a more significant concern } \\
\text { for HM. The training of the multidisciplinary } \\
\text { team must be carried out continuously to } \\
\text { raise awareness of risks and prevent hospital } \\
\text { infection to which patients are exposed. }\end{array}$ \\
\hline $\begin{array}{l}\text { A21(33) } \\
\text { Revista de } \\
\text { Enfermagem do } \\
\text { Centro-Oeste Mineiro. } \\
2017\end{array}$ & $\begin{array}{l}\text { Laboratory analysis of } 14 \\
\text { swabs was performed. }\end{array}$ & $\begin{array}{l}\text { To analyze contamination of equipment in an } \\
\text { intensive care unit before and after cleaning } \\
\text { and disinfection and propose a protocol for } \\
\text { decontamination. }\end{array}$ & $\begin{array}{l}\text { In the pre-disinfection, the bedside table, the } \\
\text { computer keyboard, and the telephone presented } \\
\text { negative growth of staphylococcus coagulase. } \\
\text { The phone remained contaminated after cleaning } \\
\text { and disinfection. The medication preparation } \\
\text { bench, the glucometer, the nursing scale, and the } \\
\text { monitor did not show contamination before or } \\
\text { aftercleaning/disinfection. }\end{array}$ \\
\hline $\begin{array}{l}\text { A22 } \\
\text { Rev Latino-Americana } \\
\text { de Enfermagem. } 2016\end{array}$ & $\begin{array}{l}\text { Systematic literature } \\
\text { review. A total of } 13 \\
\text { articles were selected. }\end{array}$ & $\begin{array}{l}\text { To describe the strategies that health } \\
\text { professionals use in the implementation } \\
\text { of the guidelines issued by the Centers } \\
\text { for DiseaseControlandPrevention in the } \\
\text { prevention of urinary tract infection } \\
\text { associated with bladder catheterization. }\end{array}$ & $\begin{array}{l}\text { It was identified: reminder systems to decrease } \\
\text { the number of people submitted to urinary } \\
\text { catheterization; audits on the practice of } \\
\text { nursing professionals, application of bundles } \\
\text { and removing the catheter when unnecessary, } \\
\text { which allows reducing the rate of catheter- } \\
\text { related urinary tract infections. }\end{array}$ \\
\hline $\begin{array}{l}\text { A23(35) } \\
\text { Revista Eletrônica de } \\
\text { Enfermagem do Vale } \\
\text { do Paraíba. } 2013\end{array}$ & $\begin{array}{l}\text { Descriptive exploratory } \\
\text { cross-sectional study, } \\
\text { with statistical data. A } \\
\text { total of } 130 \text { patients were } \\
\text { admitted, reaching } 1107 \\
\text { patients/day. }\end{array}$ & $\begin{array}{l}\text { To identify the number of nosocomial } \\
\text { infections associated with the use of the } \\
\text { central venous catheter and propose the use } \\
\text { of the infection prevention bundles method, } \\
\text { contributing to the quality of care provided } \\
\text { to the client. }\end{array}$ & $\begin{array}{l}\text { Among the } 1107 \text { patients/day with CVC, } \\
\text { the majority of infections were caused by } \\
\text { Staphylococcus aureus, which is removed } \\
\text { with a simple hand washing to avoid, bundles } \\
\text { appear, which are simple and effective } \\
\text { measures. }\end{array}$ \\
\hline
\end{tabular}

\section{DISCUSSION}

The different interventions resulting from the search were grouped according to the care used to perform imaging tests at the bedside, which contribute to safe care in terms of communication, patient identification, device care, prevention, and infection control.

In this sense, several actions when carried out properly transform care and prevent damage. Identifying patients correctly ${ }^{(29)}$ and improving the effectiveness of communication ${ }^{(30)}$ between healthcare professionals are the first two international goals for patient safety ${ }^{(36)}$.

Among the main failures in the care of critically ill patients is the transfer of information related to the care provided, which affects the quality of care, resulting in delayed, duplicated, or wrongly performed interventions ${ }^{(30)}$. It is frequent to cancel exams for not having the necessary fasting time or to keep the patient's fasting even after the cancellation of these procedures ${ }^{(37)}$. Thus, having effective communication techniques, such as the use of clear and structured language, guarantees these curity of information and the continuity of assistance ${ }^{(38)}$.

Likewise, patient identification is necessary to avoid misunderstandings due to lack of documents, namesake names, names of another nationality, changes, or difference in the date of birth and failures to include data in the system. Such situations hinder the correct identification of patients and favor the exchange of exams, procedures, and exchange of information passed on during the shift change ${ }^{(38)}$. It is crucial to ensure that an individual undergoing treatment is the one who is hospitalized in a particular unit or subjected to a specific examination or procedure, thus preventing failures, errors, or mistakes ${ }^{(39)}$.

Several factors are involved in the identification process that makes it a great challenge for health institutions. To develop strategies that promote continuous improvement of the process, proposing and implementing the promotion of the institutional safety culture, such as the involvement of managers, assistance teams, if necessary ${ }^{(29)}$.

This review allowed the identification of care with devices, whether invasive or not ${ }^{(3,15-17,20,22-26,34-35)}$ and care performed with positioning in the bed $^{(14,19)}$. Among the devices used as resources for the treatment of critically ill patients are orotracheal tubes, tracheostomy tubes, central venous catheter, peripheral venous catheter, arterial catheter, nasogastric tube, or nasoenteric tube, catheter-delay bladder and drains ${ }^{(3)}$. And the inappropriate handling of these devices place the clientele at risk ${ }^{(25)}$.

The actions listed in studies that discuss the protocol of care with drains ${ }^{(16)}$ and bypasses ${ }^{(15)}$ propose actions and suggest the 
appropriate management with the devices, the use of specific materials and equipment, which reduce the damage and decrease the associated morbidity to the method used ${ }^{(15-16)}$. Making a checklist that works as a care guide is proposed as a strategy that allows nurses to detect earlyproblems with the procedure, preventing the occurrence of adverse events ${ }^{(20)}$.

The removal of the ventilatory device in an unplanned way, called accidental extubation, can cause complications to the treatment and damage the patient's health, mainly if it occurs in patients with a decreased respiratory stimulus, sedated patient, or with neurological injuries ${ }^{(40)}$.

For this, a study ${ }^{(41)}$ demonstrates that careful positioning is essential, with the patient's decubitus change or mobilization being the main situations considered critical associated with accidental extubation, and that must be continuously observed.

In one of the studies ${ }^{(19)}$, a positioning protocol for the newborn was created which is essential for these patients, as it assists in the neuromuscular development of the patient and reduces changes and complications. Positioning is also crucial during the $\mathrm{X}$-ray for confirmation of the chest drain, a technique that requires mobilization of the patient immediately after the insertion of the drain and whenever traction is suspected ${ }^{(16)}$. In addition to the risk of traction and accidental removal, it can still cause pain during the imaging exam ${ }^{(19)}$.

Another important aspect analyzed was the performance of echocardiography exams in bed, which despite this modality eliminates the risk of transporting the patient to the exam sector, the result may be impaired due to inadequate images, as positioning is crucial to obtain good exam images. Thus, the left lateral decubitus position is recommended for bed echocardiography exams ${ }^{(14)}$.

Another device that is widely used and requires specific care is the nasogastric or nasoenterictubes. A study ${ }^{(3)}$ showed that these devices removed in an unplanned manner, being removed by the patient, due to obstruction, accidental loss or damaged device.

The use of venous catheters in critical units is common and avoiding infections is extremely important, therefore, it is necessary to clean hands, perform insertion maintenance, carry out daily monitoring, observe phlogistic signs, perform dressing, handle the catheter carefully follow-up infusions such as the use of contrast for exams ${ }^{(25-26,35)}$. A study ${ }^{(22)}$ suggests that, to avoid contrast leakage, the professional should use strategies for patient safety, including reducing the injected volume and quickly detecting the leakage.

The nurse plays a central role in maintaining the surgical dressing, in the evaluation of the surgical wound ${ }^{(23)}$ and in the evaluation of signs of urinary tract infection, as well as the need for urinary catheterization and when to remove the catheter ${ }^{(24)}$. Care with the fixation and traction of these devices are essential to avoid infection and complications for the patient.

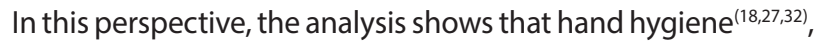
the use of personal protective equipment (PPE) ${ }^{(28)}$ and the cleaning of equipment and surfaces ${ }^{(21,33)}$ are relevant regarding to the safety of the care provided, although often ignored by professionals.

Data from a survey ${ }^{(27)}$ showed that in $56.2 \%$ of the procedures observed, hand hygiene was not performed, and professional nurses, nursing technicians and doctors had less than $50 \%$ adherence in the observed behaviors. Another study ${ }^{(18)}$ revealed that out of the 793 observations, $56.2 \%$ of them did not have hand hygiene, resulting in an adherence rate of $43.7 \%$. In a third study ${ }^{(35)}$ of 1107 patients/day with Central Venous Catheter (CVC), 14 were infected with $S$. aureus, which are removed with simple measures such as hand hygiene.

Professionals are often careless and exposed to occupational risks, either due to non-adherence to the use of Personal Protective Equipment (PPE) or due to poor hand hygiene ${ }^{(25)}$.

Hands are the primary source of contamination and the spread of infection. Despite being a simple measure and inserted in the daily routine of health professionals, most professionals do not perform hand hygiene at the moment after contact with areas close to patients ${ }^{(32)}$.

The decontamination of surfaces, materials, and equipment is part of the provision of care, as they are always in contact with patients and the professionals involved in the assistance. The presence of dirt or organic matter on surfaces, equipment, and materials contributes to the transmission of microorganisms. Therefore, in addition to hand hygiene and the use of PPE, cleaning, and disinfecting surfaces is of paramount importance to prevent health-related infection ${ }^{(33)}$.

Adherence to the five moments of hand hygiene is recommended by the World Health Organization (WHO) which must be carried out: before contact with the patient; before performing the procedure; after risk of exposure to biological fluids; after contact with the patient; and after contact with areas close to the patient, even if he has not touched the patient, caring directly or indirectly for the patient ${ }^{(42-43)}$.

Care for critically ill patients undergoing point-of-care testing must be based on scientific evidence, finding strategies that promote the efficient and safe management of the procedure is necessary to significantly decrease the practice and behaviors not recommended by the guidelines ${ }^{(27)}$. The entire multidisciplinary team must promote an appropriate intervention to guarantee the quality of care delivery to bedridden patients ${ }^{(31)}$.

\section{Study limitations}

This research was characterized by intense research and search for evidence for the construction of the protocol. The most considerable limitations of this study are the scarcity of specific literature on the care of critically ill patients when carrying out the image examination in bed and the lack of full articles.

\section{Contributions to the Area}

It is expected that this research contributes to the practice of the multi-professional team, and stimulate other production linked to safety in the care provided to critical patients, during the performance of imaging tests.

\section{FINAL CONSIDERATIONS}

Safe care is a challenge for institutions and health professionals, and it is relevant to carry out procedures that prevent adverse events in point-of-care testing.

It is necessary to train professionals concerning the safety of actions related to bedridden care, the involvement of the patient 
throughout their hospitalization, and the strengthening of strategies based on the evidence and permanent education of the team.

The prevention and management of risk incidents in health institutions and the encouragement of reporting them, aim to improve the quality and safety of care processes.
Although the care described in the selected evidence has provided subsidies for the validation of a safe care protocol for critical patients undergoing bed imaging, specific studies are needed on the patient's safety undergoing point-of-care testing and on the competence of professionals from the multidisciplinary team involving care.

\section{REFERENCES}

1. Ministério da Saúde (BR). Agência Nacional de Vigilância Sanitária. Documento de referência para o Programa Nacional de Segurança do Paciente [Internet]. Brasília: Ministério da Saúde; 2014 [cited 2016 Jun 20]. Available from: http://bvsms.saude.gov.br/bvs/publicacoes/ documento_referencia_programa_nacional_seguranca.pdf

2. Carvalho EM, Santos PR. Segurança do paciente e do trabalhador em Imagenologia: uma revisão integrativa. Rev Pesqui: Cuid Fundam [Internet]. 2017 [cited 2018 Oct 28];9(4):931-8. Available from: http://www.seer.unirio.br/index.php/cuidadofundamental/article/view/4642

3. Pereira LMV, Almeida LF, Franco AS, Marins ALC, Ribeiro GSR, Macedo M. Retirada não planejada de dispositivos invasivos e suas implicações para a segurança do paciente crítico. Rev Pesqui: Cuid Fundam [Internet]. 2018 [cited 2018 May 17];10(2):490-5. Available from: http://www. seer.unirio.br/index.php/cuidadofundamental/article/view/6106

4. World Health Organization (WHO) [Internet]. Global Patient Safety Challenge: 2005-2006 [Internet]. Geneva: WHO; 2005 [cited 2017 Mar 28]. Available from: http://www.who.int/patientsafety/events/05/GPSC_Launch_ENGLISH_FINAL.pdf

5. Moura GMSS, Magalhães AMM. Eventos adversos relacionados à assistência em serviços de saúde: principais tipos. In: Brasil. Agência Nacional de Vigilância Sanitária. Assistência Segura: uma reflexão teórica aplicada à prática [Internet]. Brasília: Anvisa; 2017, p. 65-78. [cited 2018 Oct 27];Available from: https://www20.anvisa.gov.br/segurancadopaciente/index.php/publicacoes/item/ caderno-1-assistencia-segura-uma-reflexao-teorica-aplicada-a-pratica

6. Venturi V, Viana CP, Maia LFS, Basílio MJ, Oliveira AA, Sobrinho JC, et al. O papel do enfermeiro no manejo da monitorização hemodinâmica em unidade de terapia intensiva. Rev Recien [Internet]. 2016 [cited 2018 May 17];6(17):19-23. Available from: http://www.recien.com.br/ index.php/Recien/article/view/145

7. Nascimento ERP, Trentini M. O cuidado de enfermagem na unidade de terapia intensiva (UTI): teoria humanística de Paterson e Zderad. Rev Latino-Am Enfermagem. 2004;12(2):250-7. doi: 10.1590/S0104-11692004000200015

8. Moore CL, CopelJA. Point-of-Care Ultrasonography. N Engl J Med [Internet]. 2011 [cited 2016 Jul 27];364:749-57. Available from: https:// www.nejm.org/doi/full/10.1056/NEJMra0909487

9. Almeida ACG, Neves ALD, Souza CLB, Garcia JH, Lopes JL, Barros ALBL. Transporte intra-hospitalar de pacientes adultos em estado crítico: complicações relacionadas à equipe, equipamentos e fatores fisiológicos. Acta Paul Enferm [Internet]. 2012 [cited 2017 May 15];25(3):471-6. doi: 10.1590/S0103-21002012000300024.

10. Faria JMS, Pontífice-Sousa P, Gomes MJP.O conforto do doente em cuidados intensivos - revisão integrativa. Enferm Glob [Internet].2018 [cited 2018 Jan 10];50:503. Available from: http://scielo.isciii.es/pdf/eg/v17n50/pt_1695-6141-eg-17-50-477.pdf

11. Souza MT, Silva MD, Carvalho R. Revisão integrativa: o que é e como fazer. Einstein [Internet]. 2010 [cited 2017 Oct 15];8(1):102-6. Available from: http://www.scielo.br/pdf/eins/v8n1/pt_1679-4508-eins-8-1-0102.pdf

12. Botelho LLR, Cunha CCA, Macedo M. O método da revisão integrativa nos estudos organizacionais. Gestão Soc [Internet]. 2011 [cited 2018 May 03];5(11):121-36. Available from: http://www.gestaoesociedade.org/gestaoesociedade/article/view/1220

13. Nobre MRC, Bernardo WM, Jatene FB. A prática clínica baseada em evidências. Parte l: questões clínicas bem construídas. Rev Assoc Med Bras [Internet]. 2003 [cited 2018 May 14];49(4):445-9. doi: 10.1590/S0104-42302003000400039

14. Afonso TR, Daminello E, Guimarães LA, Mônaco CG, Vieira MLC, Cordovil A, et al. Influência do Posicionamento do Paciente sobre a qualidade das imagens ecocardiográficas em exames realizados no Leito. Arq Bras Cardiol: ImagemCardiovas [Internet]. 2016 [cited 2018 Oct 27];29(4):112-7. Available from: http://departamentos.cardiol.br/dic/publicacoes/revistadic/revista/2016/portugues/Revista04/08_ artigo_original_164_port.pdf

15. Machado RC, Gironés P, Souza AR, Moreira RSL, Von Jakitsch CB, Branco JNR. Protocolo de cuidados de enfermagem a pacientes com dispositivo de assistência ventricular. Rev Bras Enferm [Internet]. 2017 [cited 2018 Oct 27];70(2):353-9. Available from: http://www.scielo.br/ pdf/reben/v70n2/pt_0034-7167-reben-70-02-0335.pdf

16. Morais ACC, Lemos MM, Marques VD, Bandeira COP. Institutional protocol to standardize the chest drainage system management, from surgery to nursing care, at a regional hospital in northern Paraná. Acta Sci Health Sci [Internet]. 2016 [cited 2018 Oct 27];38(2):173-7. Available from: http://periodicos.uem.br/ojs/index.php/ActaSciHealthSci/article/view/26972

17. Rocha AEF, Rocha FAA, Mourão Neto JJ, Gomes FMA, Cisne MSV. Cuidado de enfermagem ao paciente ventilado artificialmente: uma revisão integrativa. Essentia [Internet]. 2017 [cited 2018 Oct 27];18(1):41-53. Available from: http://www.uvanet.br/essentia/index.php/ revistaessentia/article/view/35 
18. Souza LM, Ramos MF, Becker ESS, Meirelles LCS, Monteiro SAO. Adesão dos profissionais de terapia intensiva aos cinco momentos da higienização das mãos. Rev Gaúcha Enferm [Internet]. 2015 [cited 2018 Oct 27];36(4):21-8. Available from: https://seer.ufrgs.br/ RevistaGauchadeEnfermagem/article/view/49090

19. Toso BRGO, Viera CS, Valter JM, Delatore S, Barreto GMS. Validação de protocolo de posicionamento de recém-nascido em Unidade de Terapia Intensiva. Rev Bras Enferm. 2015;68(6):835-41. doi: 10.1590/0034-7167.2015680621i

20. Gan KLJ, Tan M. Evidence-based management of patients with chest tube drainage system to reduce complications in cardiothoracic vascular surgery wards. Int J Evid Based Healthc [Internet]. 2015 [cited 2018 Oct 27];13(2):58-65. Available from: https://journals.Iww.com/ ijebh/Abstract/2015/06000/Evidence_based_management_of_patients_with_chest.4.aspx

21. Miyague AH, Mauad FM, Martins WP, Benedetti ACG, Ferreira AEGM, Mauad-Filho F. O exame ultrassonográfico como potencial fonte de infecção cruzada e nosocomial: uma revisão da literatura. Radiol Bras [Internet]. 2015 [cited 2018 Oct 27];48(5):319-23. Available from: http://www.scielo.br/pdf/rb/v48n5/pt_0100-3984-rb-48-05-0319.pdf

22. Ding S, Meystre NR, Campeanu C, Gullo G. Contrast media extravasations in patients undergoing computerized tomography scanning: a systematic review and meta-analysis of risk factors and interventions. JBI Database System Rev Implement Rep [Internet]. 2018 [cited 2018 Oct 27];16(1): 87-116. Available from: https://www.ncbi.nlm.nih.gov/pubmed/29324560

23. Vital JACP, Cruz ICF. Diretrizes para a prática baseada em evidências sobre a intervenção de enfermagem cuidado com o local de incisão cirúrgica no pós operatório de cirurgia cardíaca em UTI- Revisão Sistematizada de Literatura. J Special Nurs Care.[Internet]. 2016 [cited 2018 Oct 27];10(1): 258-70. Available from: http://www.jsncare.uff.br/index.php/jsncare/article/view/2994/763

24. Almeida TPM, Cruz ICF. Diretrizes para a prática de cuidados de enfermagem com cateter vesical em pacientes de alta complexidade: Revisão sistematizada de literatura. J Special Nurs Care[Internet]. 2018 [cited 2018 Oct 27];10(1):1983-4152. Available from: http://www. jsncare.uff.br/index.php/jsncare/article/view/3013/769

25. Silva EA, Cruz ICF. Diretrizes para a prática baseada em evidência para o controle de intervenção de enfermagem na prevenção de infecção relacionada a cateter venoso central, um desafio na prática assistência em UTI - Revisão Sistematizada da Literatura. J Special Nurs Care [Internet]. 2018 [cited 2018 May 23];10(1):1983-4152. Available from: http://www.jsncare.uff.br/index.php/jsncare/article/view/2984/757

26. Sousa FC, Pereira JC, Rezende DA, Laura C. Avaliação dos cuidados de enfermagem com o cateter venoso central em uma unidade de terapia intensiva adulto e pediátrica. Rev AdmSaúde [Internet]. 2018 [cited 2018 Oct 27];18(70).Available from: http://www.cqh.org.br/ojs2.4.8/index.php/ras/article/view/92

27. Graveto JM, Santos C, Costa PS, Fernandes E, Alarico S, Osório N, et al. Gestão do procedimento higiene das mãos por enfermeiros: desafios para saúde coletiva. Rev Bras Enferm [Internet]. 2018 [cited 2018 Oct 27];71(Suppl 1):607-12. Available from: http://www.scielo.br/pdf/ reben/v71s1/pt_0034-7167-reben-71-s1-0562.pdf

28. Silva OM, Ribeiro MC, Moraes VC, Xavier TC, Ascari RA, Frizon G. Biossegurança precaução padrão na Unidade de Terapia Intensiva: revisão Integrativa. Rev Uningá [Internet]. 2016 [cited 2018 Oct 27];49:71-8. Available from: http://revista.uninga.br/index.php/uninga/article/ view/1302

29. Panno SF, Costenaro RGS, Diaz C, Zamberlan C. Uso de pulseiras na identificação do paciente: Implicações para o cuidado seguro. Disciplinarum Sci Ciênc Saúde [Internet]. 2017 [cited 2018 Oct 27];18(1):145-55. Available from: https://www.periodicos.unifra.br/index. php/disciplinarumS/article/view/2258

30. Santos GRS, Campos JF, Silva RC. Comunicação no handoff na terapia intensiva: nexos com a segurança do paciente. Esc Anna Nery [Internet]. 2018 [cited 2018 Oct 27];22(2): 1-12. Available from: http://www.scielo.br/pdf/ean/v22n2/pt_1414-8145-ean-2177-9465EAN-2017-0268.pdf

31. Guimarães AA, Santos CFO, Silva FCS, Ferreira JCS; Freitas JS, Silva JS, et al. Quais as evidências da literatura científica relacionadas ao cuidado de enfermagem ao paciente acamado em UTI?. Rev Eletrônica Acervo Saúde [Internet]. 2018 [cited 2018 Oct 27];10:S984-90. Available from: https://www.acervosaude.com.br/doc/REAS94.pdf

32. Ferreira A, Webler JM, Silva JOM, Rozin L. Matia G. Adesão aos cinco momentos de higienização das mãos em unidades de terapia intensiva de um hospital pediátrico. Rev Saúde Pública do Paraná [Internet]. 2017 [cited 2018 Oct 27];18(2):96-104. Available from: https://www. researchgate.net/publication/323191106_Adesao_aos_cinco_momentos_de_higienizacao_das_maos_em_unidades_de_terapia_ intensiva_de_um_hospital_pediatrico

33. Mendes JR, Brasileiro MSE. Proposta de protocolo para descontaminação de equipamentos em unidade de Terapia Intensiva. Ver Enferm Centro-Oeste Mineiro [Internet]. 2017 [cited 2018 Oct 27];7(e2346):1-5. Available from: http://seer.ufsj.edu.br/index.php/recom/article/ view/2346

34. Andrade VLF, Fernandes FAV. Prevenção da infecção do trato urinário associada ao cateterismo: estratégias na implementação de guidelines internacionais. Rev Latino-Am Enfermagem [Internet]. 2016 [cited 2018 Oct 27];24: e2678. Available from: http://www.scielo.br/pdf/rlae/ v24/pt_0104-1169-rlae-0963-2678.pdf

35. Santos RA, Zago MABS, Giaretta VMA. Infecção hospitalar associada ao uso do cateter venoso central e seus cuidados. REENVAP [Internet]. 2013 [cited 2018 Oct 27];1(5):109-24. Available from: http://publicacoes.fatea.br/index.php/reenvap/article/viewArticle/1138

36. Ministério da Saúde (BR). Relatório do seminário nacional para implantação do programa nacional de segurança do paciente [Internet]. Brasília: Ministério da Saúde; 2013 [cited 2017 Nov 12]. Available from: https://www20.anvisa.gov.br/segurancadopaciente/images/ documentos/RelatorioSeminarioNacionallmplantacaodoProgramaNacionaldeSegurancadoPacienteout2013.pdf 
37. Anziliero F, Corrêa APA, Silva BA, Soler BED, Batassini E, Beghetto MG. Sonda Nasoenteral: fatores associados ao delay entre indicação e uso em Emergência. Rev Bras Enferm [Internet]. 2017 [cited 2018 Oct 27];70(2):344-52. Available from: http://www.scielo.br/pdf/reben/v70n2/ pt_0034-7167-reben-70-02-0326.pdf

38. Harada MJCS, Pedreira MLG. O erro humano e sua prevenção. In: Agência Nacional de Vigilância Sanitária. Assistência Segura: uma reflexão teórica aplicada à prática[Internet]. Brasília: Anvisa; 2017[cited 2018 Oct 27];41-55. Available from: https://www20.anvisa.gov.br/ segurancadopaciente/index.php/publicacoes/item/caderno-1-assistencia-segura-uma-reflexao-teorica-aplicada-a-pratica

39. Souza RFF, Silva LD. Estudo exploratório das iniciativas acerca da segurança do paciente em hospitais do Rio de Janeiro. Rev Enferm UERJ [Internet]. 2014 [cited 2018 Oct 27];22(1):22-8. Available from: http://www.facenf.uerj.br/v22n1/v22n1a04.pdf

40. Barros PT, Silva RM, Mesquita FOS. Cultura de segurança Associada à educação permanente: estratégias para redução do número de extubação acidental [internet]. In: Anais do II Congresso Brasileiro de Ciências de Saúde; 2017 [cited 2018 Oct 27]. Available from: https:// editorarealize.com.br/revistas/conbracis/trabalhos/TRABALHO_EV071_MD1_SA9_ID1966_15052017112452.pdf

41. Castellões TMFW, Silva LD. Guia de cuidados de enfermagem na prevenção da extubação acidental. Rev Bras Enferm [Internet]. 2007 [cited 2016 Oct 15];60(1):106-9. doi: 10.1590/S0034-71672007000100021

42. Agência Nacional de Vigilância Sanitária-Anvisa. Higienização das mãos em serviços de saúde [Internet]. Brasília: Anvisa; 2007 [cited 2018 Oct 27]. Available from:https://www.anvisa.gov.br/hotsite/higienizacao_maos/manual_integra.pdf

43. Agência Nacional de Vigilância Sanitária-Anvisa. Segurança do paciente em serviços de saúde: limpeza e desinfecção de superfícies [Internet]. Brasília: Anvisa; 2012 [cited 2018 Oct 27].Available from: https://www20.anvisa.gov.br/segurancadopaciente/index.php/ publicacoes/item/seguranca-do-paciente-em-servicos-de-saude-limpeza-e-desinfeccao-de-superficies. 